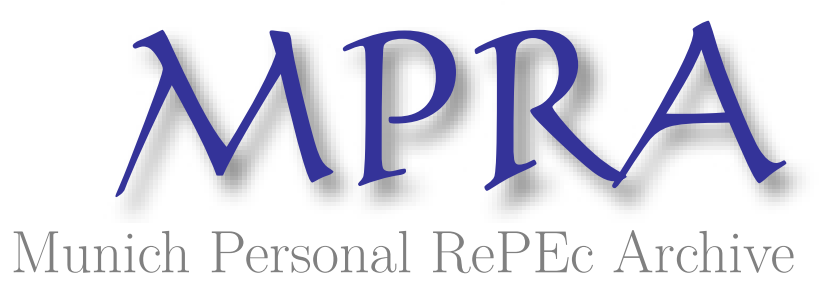

\title{
Ex-urban sprawl as a factor in traffic fatalities and EMS response times in the southeastern United States
}

Lambert, Thomas and Meyer, Peter

Indiana University Southeast, University of Louisville

December 2006

Online at https://mpra.ub.uni-muenchen.de/39008/

MPRA Paper No. 39008, posted 24 May 2012 19:03 UTC 


\section{Ex-Urban Sprawl as a Factor in Traffic Fatalities and EMS Response Times in the Southeastern United States}

\section{Thomas E. Lambert \\ and \\ Peter B. Meyer}

Many different writers (Atkinson and Oleson 1996; Barnett 1995; Burchell and Lisotkin 1995; Burchell et al., 1998; Carruthers and Ulfarsson 2002; Ciscel 2001; Ewing 1997; and Glaeser and Kahn 2003) have examined the direct and indirect costs of unplanned growth or sprawl. However, an area only recently examined is the impact of sprawl on traffic fatalities (Ewing, Schieber and Zegeer, 2003; Lucy 2003; and Lucy 2000). Besides a case study of the Chicago area, which found emergency medical services (EMS) delays due to sprawl (American Farmland Trust 1998), another issue not examined on a larger scale is the degree to which sprawl might be contributing to delays in EMS. In this research note, we develop models similar to the ones used by Reid Ewing, Richard Schieber and Charles Zegeer (2003), Stefan Felder and Henrik Brinkmann (2002) and Theodore Keeler (1994) in order to assess the impact that the built environment has on EMS response times and the rate of traffic fatalities in the southeastern United States.

Reid Ewing (1997) reviews 17 studies concerning sprawl and identifies four characteristics defining it: low-density, strip development, scattered development, and leapfrog development. Peter Gordon and Harry Richardson (1997), in their criticism of planners who promote. "compact cities," suggest that sprawl is low density, dispersed, decentralized, polycentric (many centers), and suburban. The universal mobility of the auto has allowed job and home to be miles apart. Americans are driving more every year in large part because of the increasingly spread out nature of our metro areas (U.S. Dept. of Transportation (DOT), National Transportation Statistics 1999). The 2001 National Household Travel Survey reports that although

\footnotetext{
Thomas Lambert is a Visiting Lecturer in the Department of Economics at Indiana University Southeast and an Adjunct for the College of Business and School of Urban and Public Affairs at the University of Louisville, and Peter Meyer is the Director of the Center for Environmental Policy and Management at the University of Louisville. This research was partially supported by a U.S. Environmental Protection Agency, Region 4 Grant. The authors would like to thank two anonymous referees and the editor for their help in revising and improving this article. We would also like to thank a graduate student at the University of Louisville, Georgette Higgs, for her help in preparing this manuscript and Babak Khorrami with the Fatal Accident Reporting System for his help with data needs. The usual disclaimers apply.
} 
Americans were making fewer trips by motor vehicle, average time per trip had gone up including the commute to work (U.S. Department of Transportation 2004). Edward Glaeser and Matthew Kahn (2003) contend that sprawl is a result of a society that has centered itself on the automobile.

As development continues outward, jobs, housing and services grow farther apart. In the past few decades, development patterns that require an automobile trip for every errand force many to drive more every year to accomplish the same things. The long journey to work or for shopping is now accepted as commonplace. Due to families having the luxury of several automobiles, many of these trips (over $81 \%$ ) are one-person occupied (U.S. DOT 1999). Ewing, Schieber, and Zegeer (2003) and Keeler (1994) show that higher population density is associated with lower traffic fatalities on a per capita basis. Ewing, Schieber and Zegeer create a "sprawl index" demonstrating that more sprawled metro counties (i.e., those having low general population density, large/long block sizes, and census tracts with population densities below 2,500) have higher traffic fatality rates than their less sprawled counterparts. Also, the more sprawled an area becomes the more difficult for police, fire and EMS to reach many new households and new developments, even those along existing roadways. The alternative is to build new facilities closer to the new developments, which raises the costs of public service provision.

\section{Methods}

As a measurement of the consequences of sprawl, William Lucy (2003) constructs an index measuring the likelihood of someone becoming a traffic or homicide fatality statistic in different parts of a metro area. He finds higher traffic fatality and homicide rates in exurban areas than those in central cities or the inner suburbs of fifteen metro areas.' Similarly, Reid Ewing, Rolf Pendall, and Don Chen (2002) find that traffic fatalities are much higher in what they have ranked as the top ten most sprawling metro areas versus the ten least sprawling metro areas in the United States: fifteen average annual traffic deaths versus nine average annual traffic deaths per 100,000 residents.

For this paper, we first looked at fatal traffic crashes and then average EMS run times (from time of notification to arrival of an EMS unit) to an accident site for the year 2002 in the metro areas of eight states that make up the United States Environmental Protection Agency Region 4: Alabama, Florida, Georgia, Kentucky, Mississippi, North Carolina, South Carolina, and Tennessee. Fatal traffic crash and corresponding EMS time data were found for most of the counties that make up the metro areas of these states. The metro area boundaries were those that were in existence as of 2002 (U.S. Census Bureau, County and City Data Book, 2000).

Using the U.S. National Highway Traffic Safety Administration's (NHTSA) Fatal Accident Reporting System (FARS), fatal traffic crashes and EMS times were divided as having occurred in two types of areas: urban and rural, or ex-urban. FARS uses the Federal Highway Administration's (FHWA) definition of urban and rural. This definition follows the U.S. Bureau of the Census definition of urban but "allows 
responsible state and local officials in cooperation with each other, and subject to approval by the Secretary of Transportation, to adjust the Census boundaries outward, as long as they encompass, at a minimum, the entire Census designated area" (http://www.fhwa.dot.gov/planning/census/faqa2cdt.htm, U.S. DOT 2003). All else is defined as "rural." With the 2000 Census, the U.S. Census Bureau classifies populations and land areas as "urban," "rural, non-farm" and "rural, farm" according to population density. Before 2000 , the definition of urban hinged upon municipal incorporation and total population, not on population density thresholds. For the 2000 Census, an urbanized area or urban cluster "consists of core census block groups or blocks that have a population density of at least 1,000 people per square mile and surrounding census blocks that have an overall density of at least 500 people per square mile" whereas the classification "rural' consists of all territory, population, and housing units located outside of urbanized areas and urban clusters" which means a population density below 500 per square mile (http:// www.census.gov/geo/www/ua/ua_2k.html). A census block group and a census block are sub-components of a census tract and are smaller than an actual census tract. FARS therefore follows the Census Bureau's designation of what is considered urban and rural in each area as far as population density is concerned unless state and local officials have gone beyond urbanized areas and urbanized cluster boundaries.

All of the Metropolitan Statistical Areas' (MSA) urban core counties (those with cities of population of 50,000 or more) for which we had data, had "rural" fatal crashes and "rural" EMS run times." For example, in 2002, Miami-Dade County, Florida had 226 fatal crashes classified as urban and 83 classified as rural or ex-urban. According to FARS, the urban EMS time from notification until arrival was 5.9 minutes for urban fatal crashes and 7.2 minutes for rural or ex-urban accidents for Miami-Dade. In 2002, the U.S. average EMS response time from notification to arrival was 6.51 minutes for urban fatal crashes and 12.11 minutes for rural fatal crashes (NHTSA FARS 2002). For the metro counties studied in our paper, the corresponding EMS times were 7.6 minutes for urban and 10.7 minutes for ex-urban from notification to time of arrival. For fatal crashes per 10,000 population, the average was 2.5 for urban fatal crashes and 6.3 for ex-urban fatal crashes.

Like other studies, the number of fatal traffic crashes was adjusted on a per 10,000 population basis. Again, using Miami-Dade County as an example, approximately $81 \%$ of the county's land mass is classified as rural, non-farm because of low population density whereas in Louisville-Jefferson County, Kentucky, around $32 \%$ of the county's land mass is identified as rural, non-farm. The 226 urban, fatal crashes that occurred in Miami-Dade County were divided by the total population per 10,000 of Miami-Dade County classified as urban, whereas the 83 rural, fatal crashes were divided by the total population per 10,000 of Miami-Dade County classified as rural, non-farm or ex-urban.

Given that the FARS data might be classifying some fatal crashes as urban because of state and local boundaries going beyond the Census Bureau's urbanized area or urbanized cluster boundaries, we believe our estimates of rural or ex-urban accidents per capita might be an undercount. Our estimates are therefore a little 
biased in favor of showing a slightly lower fatal crash rate per capita in ex-urban areas than what would ordinarily be the case because if Census boundaries were followed throughout these metro areas, the urban fatal crashes would be fewer and urban EMS response times would probably be lower. Additionally, the FARS data might be showing EMS times for urban areas that were slightly longer than what would be the case if FARS used Census boundaries for urban areas (i.e., some of the EMS times counted as urban were for areas outside of the Census' urbanized areas and are actually ex-urban times). Our use of the FARS classification of rural as ex-urban favored the null hypotheses that there were no differences in the urban and ex-urban fatal accident rates and EMS times.

Also, we did not use any data related to what the Census Bureau classifies as rural and farm because our interest was in new, fringe residential development versus older, urban and suburban areas and because the total land area for these counties were either classified as urban or rural, non-farm. No land area was classified as rural, farm in these metro counties. Unfortunately, there is not a "suburban" category used by the Census, so rural and non-farm was used as an ex-urban classification. ${ }^{3}$

Population density numbers for each county were calculated for both urban populations (urban population divided by the number of urban, square miles) and for ex-urban populations (rural, non-farm population divided by the number of square miles designated as rural, non-farm). We did not use the exact same methods as Ewing, Schieber, and Zegeer in calculating at the census tract level, the average block size and population thresholds above 12,500 and below 2,500. However, in order to arrive at a "sprawl index" as they did, we used the Census Bureau designations of urban and rural, non-farm (the latter of which is ex-urban) and were able to approximately match the built environment in each county with the FARS data that are classified as urban and ex-urban. ${ }^{4}$

Since we were interested in how development patterns affect EMS response times for all emergencies and not just traffic fatalities, we adjusted the urban and exurban EMS times for the urban and ex-urban populations to which they corresponded similar to how the fatal crash variable was adjusted. For example, an average urban EMS run time of 10 minutes corresponding to a population of 100,000 would be divided by $10(-100,000 / 10,000)$ to get an adjusted EMS time of one minute whereas an average ex-urban EMS time of fifteen minutes for a population of 25,000 would be divided by $2.5(-25,000 / 10,000)$ to get an adjusted EMS time of six minutes. These adjustments were made to reflect the fact that although urban EMS times were usually lower than ex-urban EMS times, the urban EMS units had to serve a greater number of people and typically got a greater number of calls than ex-urban EMS units. Additionally, the FARS data might be showing EMS times for urban areas that were slightly higher than would be the case if FARS used Census boundaries for urban areas (i.e., some of the EMS times counted as urban are for areas outside the Census' designated urbanized areas). The typical challenge for EMS units is to be deployed in such a way as to minimize the time or distance traveled to an emergency given emergency services resources and demand constraints (or "demand nodes") that are often a function of population levels (Ball and Lin 1993; 
Pirkul and Schilling 1988; Schilling 1982). Our adjustment for population served was similar to the method used by Tarald Kvalseth and John Deems (1979) in Atlanta in that we were trying to adjust EMS demand and service on a per capita basis for the purposes of comparing different groups or areas on a comparable basis. Susi Steele (1993) writes that with regard to planning EMS services, "the planning process is never over, since population concentrations and demand patterns constantly change" (63).

For fatal crashes, we looked at crashes involving all modes of transportation. ${ }^{5}$ Following Ewing, Schieber and Zegeer; we used a log-linear model of the regression equation,

$$
\operatorname{Ln} Y=\beta_{0}+\beta_{1} \operatorname{Ln} X_{1}+\beta_{2} \operatorname{Ln} X_{2}+\beta_{3} \operatorname{Ln} X_{3}+\beta_{4} \operatorname{Ln} X_{4}+\varepsilon
$$

To estimate the dependent variable of the natural $\log$ of the fatal crashes per 10,000 urban population $(n=122)$ or per 10,000 ex-urban population $(n=122)$ for the 122 metro counties in the southeastern United States ( $\mathrm{Ln} Y$ ), we used the following independent variables:

Ln $X_{1} \quad$ Log of the urban or ex-urban population density per county. As discussed above, the population for each was divided by the corresponding land area for each. There were 122 population densities for the urban population of each county and 122 population densities for the ex-urban population of each county.

$\mathrm{Ln} \mathrm{X}_{2} \quad$ Log of the ratio of urban or ex-urban land area to the total county land area. This controlled for how much of a county is developed versus non-developed in terms of urban versus ex-urban population densities. There were 122 urban land area to total county land area ratios and 122 ex-urban land area to total county land area ratios. These two different ratios for each county always summed to one since the metro counties had no land areas that were farmland (rural and farm).

Ln X $\mathrm{X}_{3} \quad$ Log of the urban and ex-urban per capita income, 1999. This was used by Ewing, Schieber, and Zegeer (2003) and Keeler (1994) as a control variable. Once again, there were 122 urban and 122 exurban values. Keeler found higher income and better educated areas associated with lower crash rates.

Ln $\mathrm{X}_{4} \quad$ Log of the highest allowable motor vehicle speed. Like Keeler (1994) we also tried to explain variations in fatal crashes due to speed. We use a method similar to his of using the highest allowable speed on a U.S. Interstate Highway per county. For MSA core counties, and for both their urban and ex-urban areas, this is 55 miles per hour (MPH). Whereas for peripheral counties in a MSA, both urban and ex-urban, we use $65 \mathrm{MPH}$ for Kentucky counties and $70 \mathrm{MPH}$ for counties in the other states (which is the 
highest speed allowed outside of a major city in the seven other states). This is an important factor because NHTSA (Traffic Safety Facts 2001: Rural/Urban Comparison) points out that "ovet $70 \%$ of the fatal crashes on roadways of $55 \mathrm{MPH}$ or higher occur in rural areas" whereas around $70 \%$ of those on roadways with speed limits of $40 \mathrm{MPH}$ or below are in urban areas.

Next we examined average EMS service times for both urban and ex-urban areas within these same 122 metro counties. Using models similar to Felder and Brinkmann (2002) and Kvalseth and Deems (1979) we again used a log-linear model regression equation,

$$
\operatorname{Ln} Y=\beta_{0}+\beta_{1} \operatorname{Ln} X_{1}+\beta_{2} \operatorname{Ln} X_{2}+\beta_{3} \operatorname{Ln} X_{3}+\varepsilon
$$

where the log of the average EMS time in 2002 per 10,000 population was the dependent variable ( $\operatorname{Ln} \mathrm{Y}$ ) with the following variables as independent variables:

$\operatorname{Ln} X_{1} \quad$ Log of the urban or ex-urban population density per county. This is the same independent variable used in the model of fatal crashes above.

$\mathrm{Ln} \mathrm{X}_{2} \quad$ Log of the ratio of urban/ex-urban land area to the total county land area. This is the same independent variable used in the model of fatal crashes above.

Ln X $\mathrm{X}_{3} \quad$ Log of the urban and ex-urban per capita income, 1999. Again, this is used as a control variable, but, as used by Felder and Brinkmann (2002), it can be used as a measure of a community's ability to dedicate resources to EMS provision and as a measure of the demand of citizens in an area for health, well being, and safety as a normal good (i.e., as income goes up, the greater their demand for health, well-being and safety, all other things held constant). Felder and Brinkmann's findings support this view. We could not find any databases that showed the resources, personnel, or expenditures that these counties or their individual municipalities put forth on EMS provision, so therefore this variable was chosen as a proxy variable. ${ }^{6}$

\section{Results}

Table 1 confirms the findings of Ewing, Schieber, and Zegeer (2003) for this part of the United States using a slightly different model. Densely settled urban portions of these southern metro counties have lower fatal crashes per capita than their ex-urban counterparts. Also, the more urbanized the land area of the county, the lower the fatal crashes per 10,000 residents as well. Incidentally, Ewing, Schieber, and Zegeer (2003) mention that the southern and southwestern states typically have the most 
sprawled areas in the United States. Speed is also a significant factor. As William Lucy (2003) points out, ex-urban areas usually have higher speed limits along with many heavily traveled two lane roads. With the exception of the per capita income variable, all of the independent variables are statistically significant at either $p<.001$ or $\mathrm{p}<.05$.

Table 1. Regression Analysis of Fatal Traffic Crash Rates

Ln of All-Mode Fatal Crashes (Coefficients and t-statistics)

\begin{tabular}{lc}
\hline \hline & Metro Area Counties in Southeastern \\
& \multicolumn{1}{l}{ United States } \\
\hline Constant & 0.642 \\
Ln Population Density & 0.45 \\
Ln Ratio of Urban/Non-urban & $(-5.09)^{* * *}$ \\
Land Area to Total Land Area of & 0.30 \\
the County & $(-4.12)^{* * *}$ \\
Ln Per Capita Income, 1999 & 0.19 \\
& $(0.70)$ \\
Ln Maximum Speed & 2.88 \\
& $(2.24)^{*}$ \\
Adjusted $\mathrm{R}^{2}$ & 0.509 \\
Sample size & 244 \\
\hline
\end{tabular}

Table 2 shows that there is a potential risk associated with ex-urban settlement patterns because of longer EMS run times in these areas of the metro counties. For every $10 \%$ increase in population density, there is a $10.4 \%$ decrease in EMS run time. The model explains around $75 \%$ of the variation in EMS run times adjusted for population. Admittedly, the longer run times in ex-urban areas could not only be occurring because of sprawl but also because of the lack of financial resources that some EMS jurisdictions have. However, the per capita income variable is not statistically significant, so community affluence possibly does not matter that much with the provision of emergency services. At the same time, it is well established in the public finance literature that up to a certain population maximum, large economies of scale exist in the provision of public services due to the compactness of many cities. Despite a large number of residents to serve, average costs go down over a densely settled geographic area when it comes to the provision of police, fire and sanitation (O'Sullivan 2003, 512; Rosen 1992, 535). Our results indicate this is accurate since shorter EMS run times correspond to more densely settled areas. 
Table 2. Regression Analysis of Variations in Emergency Services Time Ln of EMS Response Time Rates from Notification to Arrival at Scene (Coefficients and tstatistics)

Metro Area Counties in Southeastern United States

Constant

Ln Population Density

Ln Ratio of Urban/Non-urban Land

Area to Total Land Area of the County

Lon Per Capita Income, 1999

Adjusted $\mathrm{R}^{2}$

Sample size
8.22

$-1.04$

$(-26.96)^{* * *}$

0.87

$(-15.28)^{* * *}$

$-0.28$

$(-1.24)$

0.755

244

$* \mathrm{p}<.05 \quad * \mathrm{p}<.01 \quad * * \mathrm{p}<.001$

Although our data came from EMS response times to traffic accidents, we see no reason why the response times would be that different for other emergencies.

\section{Discussion}

With possible medical complications or death from delayed EMS response, sprawl can cost many communities much more than increasing expenditures for emergency technicians, medical equipment, etc. in order to keep up with new housing development. Besides the emotional and physical suffering and pain caused with motor vehicle accidents and traffic fatalities, there are also economic costs as well. According to the NHTSA, the cost of all motor vehicle crashes in the United States in 2000 was approximately $\$ 230.6$ billion of which $9 \%$ will be paid for with public funds (The Economic Impact of Motor Vehicle Crashes 2000, Summary. U.S. DOT, NHTSA 2001). The lifetime cost for each fatality to our society is almost $\$ 1$ million of which over $\$ 800,000$ is due to lost workplace and household productivity. Additionally, present and future medical costs due to injuries are estimated to be $\$ 32.6$ billion for accidents occurring in 2000.

According to the American Red Cross, quick response time to medical emergencies can mean the difference between life and death. For example, four to six minutes after cardiac arrest, brain damage is possible. Six to ten minutes after this, brain damage is likely, and beyond ten minutes, irreversible brain damage is certain. 
Six minutes is also a crucial time in case of fire emergencies (American Red Cross 1998).

The power of EMS to save lives and to help the critically ill or injured is underscored by studies, which show that decreases in the U.S. homicide rate over the last 40 years have been partially due to better and more pervasive emergency care. Anthony Harris, Stephen Thomas, Gene Fisher and David Hirsch (2002), find that improvements in emergency services from 1960 to 1999 helped to lower the murder rate by $70 \%$. This trend had already been observed in Memphis, Tennessee and other communities by the early 1990s (Giacopassi, Sparger and Stein 1992).

When homebuyers move into a newly built neighborhood, they also "purchase" local police services, fire protection, street lighting, sanitation services, and so on, provided by the local government. Charles $M$. Tiebout (1956) recognized the patterns of taxing and spending that encompass all goods, services, and costs associated with residing in a locality. The public choice view of allowing local jurisdictions to compete for residents by offering different tax and service packages is supported by Tiebout's theory of public services. The central argument of the public choice perspective, as reflected in Tiebout's model, is that citizens operating within local jurisdictions create a quasi market of local taxes and public goods "packages" via "voting with their feet" (Lyons and Lowery 1989, 541).

Therefore, the movement from city to outlying areas is the result of thousands of families basing decisions on a host of powerful attractions offered by competing jurisdictions. The attractions include: lower prices, cheaper land, lower taxes (or better services for the same or more in taxation), privacy, and "country living." The effect of rising incomes and inexpensive transportation for many families has prompted many to leave the city as well (Mieszkowski and Mills 1993). Sometimes the government inadvertently makes the attractions even more powerful with subsidies like low-interest mortgages, new schools, and new roads and highways (Atkinson and Oleson 1996; Burchell et al. 1998). Each household's decision is made in its own apparent best interest after weighing the costs and benefits. The Tiebout view also assumes that each individual or family acts fully rational and has perfect information about their choices (Rosen 1992, 530).

However, choices are often made without full knowledge of the costs, either to the family itself or to society as a whole, due to the fact that that most make choices using "bounded rationality" or because they have imperfect information about different costs and benefits. Often new homesteaders move into an area with less than perfect information and do not make all decisions rationally, i.e., weighing all costs and benefits. Lucy (2003) points out that surveys show that most new homebuyers consider area schools and crime rates but do not give that much thought to local public transportation, access to roads or to retail locations (1568). It is therefore possible that some suburban and ex-urban homesteaders do not consider how close they are to the nearest hospital or fire-fighting or emergency services unit when purchasing a home.

Even if these homesteaders believe the benefit of their large lot homes and/or lower taxes is worth sacrificing the public services that typically go along with 
urban living, they may not be aware of other costs that may come later. For example, many suburban and ex-urban dwellers may consider that the long commute time to work is worth the trouble to enjoy the type of home they have. However, as others follow them to exurbia, traffic congestion may ensue during rush hours to make their commute to work even longer. A suburban or ex-urban resident may believe that he or she will have to wait longer for EMS than an urban resident, but may underestimate the length of time.

Many home dwellers assume the risks of living in remote areas but may not fully appreciate them. Similarly, owners and operators of motor vehicles take risks by not wearing safety belts or by engaging in risky behavior, such as driving substantially over the speed limit. Although a negative consequence of such a decision (e.g., an accident) may be improbable, the consequences of a single incident may be dire. Obviously, it is impossible to stop everyone from undertaking risky behavior, but we give incentives or disincentives to minimize such behavior. These mechanisms are already in place to one extent or another-inexpensive auto insurance rates for good drivers, speeding fines, etc. One issue that needs to be explored is whether it is possible to create an environment that minimizes traffic fatalities and delayed emergency services. A built environment that is more compact with regard to development and focuses less on automobile usage could be such an environment.

The opportunity costs of extending more and better emergency services to exurbia need to be examined as well. The explicit financial savings by not providing adequate services need to be balanced against the increased harm done by not getting to someone in time. Possible deaths or impairments from delayed responses could possibly be projected and actuarially calculated, and a comparison could be made of these costs against the savings of not providing a higher level of service.

If the economies of scale in ex-urban areas are lower, then providing greater services may not always be cost efficient. However, as mentioned earlier, the costs of delayed responses could be potentially high. Therefore, a benefit-cost analysis of new developments needs to factor in such costs. If the implicit costs are higher than expected, either greater emergency service provisions in a remote area may be warranted despite some cost inefficiencies, or a new residential development project could be postponed.

One possible public policy consequence of delayed emergency services is that county governments may want to create impact fees or may want to start factoring into their existing impact fees for newly developed areas the costs of extending police, fire and emergency services. Currently, most of these fees or taxes only consider public services such as sewers, roads, and bridges (Nelson and Moody 2003; O'Sullivan 2003, 240-241). With many local governments reluctant to increase property taxes, this may be a way to either pay for extending more services or for slowing new development. The other alternative, as suggested by Atkinson and Oleson (1996) among others, is for the states to enable regional planning among counties and to create more incentives for such regional planning so as to minimize sprawl and to minimize regional fiscal disparities. 
Either of these two outcomes (increasing the services or curbing new development) are roles of local government that could be deemed appropriate public goods. In other words, such goods are often warranted on the basis that individuals often make decisions with asymmetric or less than perfect information. It is a role of government to correct for such bounded rationality and market imperfections. A regional planning approach among local governments may be the best way to control for or to prevent the negative consequences of uneven, sprawled development.

\section{Notes}

1. Exurbia is defined as "a residential area outside of a city and beyond suburbia." (http://Websterdictionary.org/definition/exurbia).

2. Not all metro counties of the MSAs had both fatal crash data as well as EMS run times. For the state of Alabama, FARS only gave data for Jefferson County, the home county for Birmingham.

3. We would like to emphasize that we are only looking at metropolitan area counties since we are concerned with the possible impacts of sprawl with regard to traffic accidents and delayed emergency medical services. Our use of the concept "rural, non-farm" is using the Census Bureau's definition of rural, non-farm. It is not a residual of what comes after the urban space since these counties do not have rural, farmland areas. According to the Census Bureau:

For Census 2000, the Census Bureau classifies as "urban" all territory, population, and housing units located within an urbanized area (UA) or an urban cluster (UC). It delineates UA and UC boundaries to encompass densely settled territory, which consists of:

- core census block groups or blocks that have a population density of at least 1,000 people per square mile and

- $\quad$ surrounding census blocks that have an overall density of at least 500 people per square mile

$\mathrm{UA}$ or UC.

In addition, under certain conditions, less densely settled territory may be part of each

The Census Bureau's classification of "rural" consists of all territory, population, and housing units located outside of UAs and UCs. The rural component contains both place and nonplace territory. Geographic entities, such as census tracts, counties, metropolitan areas, and the territory outside metropolitan areas, often are "split" between urban and rural territory, and the population and housing units they contain often are partly classified as urban and partly classified as rural.

(Source: www.census.gov/geo/www/ua/ua_2k.html)

Rural, non-farm areas are defined as those not having households or housing units with agricultural sales in 1999 (Census 2000, Urban and Rural Classification, www.census.gov/geo/www/ua/ ua_2k.html). By definition, these areas have population densities under 500 people per square mile.

4. We chose not to use the U.S. Department of Agriculture's National Resources Inventory (NRI) for metro regions because we have split each county into an urban versus suburban/ex-urban dichotomy-two observations, not one, per county.

5. Although fatalities from motorcycle accidents are often high, we could find no database to allow us to control for this (such as local motorcycle helmet laws, enforcement of helmet laws, number of bikes registered per county, etc.).

6. The number of hospitals per county according to the Census Bureau's County Business Patterns 2002 could be used as a proxy for EMS, but since we have divided each county into two parts, this data is not useful since establishment numbers and personnel for hospitals are only given at the county level in the aggregate. The Census Bureau's 2002 Census of Governments provides the number of paid police, firefighters, and health care workers at the county and municipal levels. However, since EMS 
could be in any one of these three categories (it is not listed separately), and since many EMS workers are volunteer, this data is not of much use for our research either.

\section{References}

American Farmland Trust. "Living on the Edge: The Costs of Scattered Development." March, 1998. http://www.farmlandinfo.org.

American Red Cross, Community CPR. St. Louis, MO: Mosby Lifeline 38, 1998.

Atkinson, Glen, and Ted Oleson. "Urban Sprawl as a Path Dependent Process." Joumal of Economic Issues 30, no. 2 (June 1996): 609-614.

Ball, Michael O., and Feng L. Lin. "A Reliability Model Applied to Emergency Service Vehicle Location." Operations Research 41, no. 1 (1993): 18-36.

Barnett, David. The Fractured Metropolis. New York: Harper-Collins Publishers, 1995.

Burchell, Robert, Naveed Shad, David Listokin, Hilary Phillips, Anthony Down, Samuel Seskin, Judy S. Davis, Terry Moore, David Helton and Michelle Gall. The Costs of Sprawl-Revisited. Washington, D.C.: Transit Cooperative Research Program, Report 39, National Academy Press, 1998.

Burchell, Robert, and David Listokin. Land, Infrastructure, Housing Costs and Fiscal Impacts Associated with Growth: The Literature on the Impacts of Sprawl versus Managed Growth. Newark, New Jersey: Center for Urban Policy Research, Rutgers University, 1995.

Carruthers, John I. And Gudmundur F. Ulfarsson. "Fragmentation and Sprawl: Evidence from Interregional Analysis." Growth and Change 33, Summer (2002): 312-340.

Ciscel, David. "The Economics of Urban Sprawl: Inefficiency as a Core Feature of Metropolitan Growth." Journal of Economic Issues 35, no. 2 (2001): 405-413.

Ewing, Reid H. "Is Los Angeles Style Sprawl Desirable?" Joumal of the American Planning Association 63 no. 1 (1997): 107-126.

Ewing, Reid H., Rolf Pendall, and Don Chen. "Measuring Sprawl and its Impact." Washington, D.C.: Smart Growth America, 2002.

Ewing, Reid, Richard A. Schieber, and Charles V. Zegeer. "Urban Sprawl as a Risk Factor in Motor Vehicle Occupant and Pedestrian Fatalities." American Joumal of Public Health 93 no. 9 (2003): 1541. 1545.

Felder, Stefan, and Henrik Brinkmann. "Spatial Allocation of Emergency Medical Services: Minimizing the Death Rate or Providing Equal Access?" Regional Science and Urban Economics 32, no. 1 (2002): $27-45$.

Giacopassi, David J., Jerry R. Sparger, and Preston M. Stein. "The Effects of Emergency Medical Care on the Homicide Rate: Some Additional Evidence." Journal of Criminal Justice 20, no. 3 (1992): 249. 252.

Glaeser, Edward L., and Matthew E. Kahn. "Sprawl and Urban Growth." National Bureau of Economic Research Working Paper Series. Working Paper 9733. Cambridge, Massachusetts, 2003.

Gordon, Peter, and Harry W. Richardson. "Are Compact Cities a Desirable Planning Goal?" Joumal of the American Planning Association 63, no. 1 (1997): 95-106.

Harris, Anthony, Stephen H. Thomas, Gene A. Fisher, and David J. Hirsch. "Murder and Medicine: The Lethality of Criminal Assault 1960-1999," Homicide Studies. Thousand Oaks, CA: Sage Publications, 2002.

Keeler, Theodore E. "Highway Safety, Economic Behavior, and Driving Environment." American Economic Review 84 no. 3 (1994): 684693.

Kvalseth, Tarald O., and John M. Deems. "Statistical Models of the Demand for Emergency Medical Services in an Urban Area." American Journal of Public Health 69, no. 3 (1979): 250-255.

Lucy, William H. "Watch Out: It's Dangerous in Exurbia." Planning November 2000: 14-17.

—. "Mortality Risk Associated with Leaving Home: Recognizing the Relevance of the Built Environment." American Joumal of Public Health 93, no. 9 (September 2003): 1564-1569.

Lyons, William E., and David Lowery. "Government Fragmentation versus Consolidation: Five Public Choice Myths about How to Create Informed, Involved, and Happy Citizens." Public Administration Review 49, no. 6 (December 1989), 533-543. 
Mieszkowski, Peter, and Edwin S. Mills. "The Causes of Metropolitan Suburbanization." The Joumal of Economic Perspectives 7, no. 3 (1993): 135-147.

Nelson, Arthur C., and Mitch Moody. "Paying for Prosperity: Impact Fees and Job Growth." Discussion Paper. The Brookings Institution Center on Urban and Metropolitan Policy, 2003. http://www.brookings.edu/es/urban/.

O'Sullivan, Arthur. Urban Economics, $5^{\text {th }}$ Edition. New York: McGraw-Hill Publishers, 2003.

Pirkul, Hasan, and David A. Schilling. "The Siting of Emergency Service Facilities with Workload Capacities and Backup Service." Management Science 34, no. 7 (1988): 896-908.

Rosen, Harvey. Public Finance, $3^{\text {nd }}$ Edition. Boston, MA: Irwin Publishers, 1992.

Schilling, David A. "Strategic Facility Planning: The Analysis of Options." Decision Sciences 13 no. 1 (1982): 1.14 .

Steele, Susi B. Emergency Dispatching: A Medical Communicator's Guide. Englewood Cliffs, NJ: Prentice Hall, 1993.

Tiebout, C. M. "A pure theory of local expenditure." Joumal of Political Economy 64, no. 5 (1956): 416-424.

U.S. Census Bureau. 2000 Census of Population and Housing. www.census.gov.

-. Census 2000 Utban and Rural Classification. 2000 Census of Population and Housing. www.census.gov.

- 2002 Census of Governments. http://www.census.gov/govs/www/02PubUsedoc_GovOrg.html

-. County Business Patterns, 2002. http://censtats.census.gov/cbpnaic/cbpnaic.shtml

-. County and City Data Book: 2000. hetp://www.census.gov/prod/www/ccdb.html

U.S. Department of Transportation, Bureau of Transportation Statistics. Pocket Guide to Transportation. BTS99.06R, 1999. http://www.bts.gov/pg.pdf.

—. National Transportation Statistics 1999. http://www.bes.gov

-. National Household Travel Survey, 2001 (released in 2004). http://nhts.ornl.gov/2001/pub/ STT.pdf

U.S. Department of Transportation, Federal Highway Administration. "2003 Conditions and Performance Report." Washington, DC: U.S. Government Printing Office, 2003.

"Frequently Asked Questions: Applying 2000 Census Data to Urbanized and Urban Areas." March 31, 2003. http://www.fhwa.dot.gov/planning/census/faqa2cdt.htm

U.S. Department of Transportation, National Highway Traffic Safety Administration. The Economic Impact of Motor Vehicle Crashes 2000, (2001). http://www.nhtsa.dot.gov/people/economic/ EconImpact2000/state_costs.htm.

- Traffic Safety Facts 2001: Rural/Urban Comparison. http://www.nhtsa.dot.gov.

-. Fatal Accident Reporting System. http://www-fars.nhtsa.dot.gov.

-Traffic Safety Facts 2002: A Compilation of Motor Vehicle Crash Data from the Fatality Analysis Reporting System and the General Estimates System (Early Edition). Washington, D.C.: U.S. Government Printing Office, 2002.

Webster's Dictionary. hrtp://www.webster-dictionary.org/definition/exurbia. 